\title{
Alfabetización audiovisual y creación literaria ${ }^{22}$
}

\author{
Media literacy and literary creation
}

\author{
Ida Valencia Ortiz \\ Recibido: 20 de Marzo 2013. Aprobado: 30 de Abril de 2013
}

\begin{abstract}
Resumen
La necesidad de vincular los hipermedia audiovisuales en los procesos educativo y artístico convocados por la literatura desde la universidad, responde a que la población académica es a la vez público-espectador que requiere de espacios creativos en los que pueda expresarse con lenguajes similares a los que diariamente consume: verbal, imagen, sonido, movimiento. Lograr que estudiantes y docentes realicen productos audiovisuales en sus actividades pedagógicas significa una complementariedad estimulante, compleja, agresiva y provocadora que desautomatiza la labor enseñanza-aprendizaje e integra: diversos ámbitos de la comunidad participante (más allá de la escuela), diversas asignaturas del pensum y conocimientos ancestrales con inmediatos sin eliminarse entre sí. Estas dinámicas potencian la participación activa, la imaginación, el debate, las propuestas particulares, en favor de una perspectiva artística e investigativa que integre literatura, audiovisuales y educación.
\end{abstract}

Palabras clave: Alfabetización audiovisual; Creación literaria; Educación artística; Medios audiovisuales.

\begin{abstract}
The need to link the audiovisual hypermedia in educational and artistic processes convened by the literature from the University responds to the academic population is both public- viewer requires creative spaces that can be expressed with language similar to that consume daily : verbal, image, sound, movement. Getting students and teachers audiovisual products made in their educational activities means an exciting, complex, aggressive and provocative complementarity desautomatiza teaching and learning and integrates work : various areas of the participating community (beyond school ), various curriculum subjects and ancestral knowledge without immediate eliminate each other . These dynamics enhance active participation, imagination, debate, particular proposals in favor of an artistic perspective that integrates research and literature, audiovisual and education.
\end{abstract}

Keywords: Media literacy; Literary creation; Artistic education; Media.

En la era del internet las posibilidades de vincular literatura y entornos virtuales magnifica la complementariedad óptima para estimular la imaginación y generar nuevas analogías, investigaciones particulares que impliquen explorar los diferentes lenguajes, más allá del utilizado para satisfacer las necesidades comunicacionales hipermediáticas inmediatas. Incidir en las actividades humanas desde la academia, la escuela y el arte literario en esta

\footnotetext{
${ }^{22}$ Ensayo resultado de la investigación de la autora sobre la vinculación entre audiovisual y literatura, anclada al grupo de Narrativa colombiana de la Universidad del Valle.
} 
contemporaneidad virtualizada y objetotecnologizada, implica levantar "la piel de la cultura", adentrarse a transvasar aquello "que limita la actividad lúdica al entretenimiento, la lectura a la información, la enseñanza a la instrucción y el aprendizaje a la mera decodificación o entrenamiento."

Es necesario que la educación universitaria entregue herramientas actualizadas a $1 @ s$ docentes en potencia, para que al momento de ejercer en la educación básica y secundaria, puedan construir y ser un puente que conecte la colectividad con la expresión artística, el conocimiento enciclopédico, la situación y la condición individual externas a la escuela. Una mixtura entre la necesidad de conocer y el entretenimiento. Sin que uno y otro se equiparen con aburrido y divertido.

Trabajar con la cápsula cultural de la enseñanza escolar como algo aburrido: "lo escuelero", reclama docentes creativos que con los escasos y mínimos recursos, evidentes por la superpoblación, sitúen espacios donde los estudiantes puedan expresarse y ser "autores de su pensamiento". Es la experiencia artística la que entrega esta opción, y en su modalidad audiovisual constituyen un atractivo para quienes participan en ella. Se pueden encontrar ya testimonios sobre estos procesos.

Desde luego la idea es replicar este modelo en la enseñanza universitaria, pues 1@s estudiantes llegan en las mismas que la población de "colegio": inmersos en una brecha actitudinal y conceptual en un mundo que consideran resuelto. Se evidencian falencias escriturales, expresivas, creativas, interpretativas que reclaman un Waking life (Despertar a la vida). Se tienen manjares pero no se sabe cómo se comen, con qué. Estamos en el terreno de "lo subutilizado", ¿tanta apertura tecnológica para continuar diciendo lo mismo? Es imperativo dejar ya de reproducir el pensamiento de otros como lo eterno- incambiableverdadero.

Las relaciones entre Literatura y audiovisuales constituyen un área de investigación que se detiene en la reflexión teórica, creativa y crítica de los diversos productos cinematográficos, videográficos, webgráficos como discursos cargados de sentidos y contenidos, que por hacer parte de las costumbres humanas resignifican las maneras expresivas del arte, de la industria, del comercio, de la tecnología y de la educación.

Es imprescindible en la era de las pantallas y la imagen en movimiento que la comunidad estudiantil universitaria se forme como público audiovisual, particularizando espectador@s 
activos que interpreten los discursos audiovisuales, escribiendo sobre ellos, a partir de ellos, creando nuevas obras que exploren estéticamente las historias o las imágenes de interés. La acción de quien especta, es distancia de la masa que consume pasiva (eje del interés industrial) va encaminada a enfrentar críticamente las nuevas tecnologías generadoras de nuevas necesidades, nuevos comportamientos, nuevos tipos de arte, nuevas fusiones, nuevos sujetos que es preciso develar, interpretar, aproximarse. Es indispensable reconocer el "carácter heterogéneo", multidisciplinar de las imágenes en movimiento, y el multiverso simbólico que suscitan las relaciones complementarias con el texto escrito, con el sonido. Trascender las discusiones binarias que reducen tal o cual expresión arguyendo simpleza, facilidad, desconociendo la diversidad de perspectivas latentes, por ejemplo en la videografía, un campo al alcance de la mano, de los sentidos, si evidenciamos lo obvio que es la cantidad de cámaras con las que se cuentan actualmente.

Aclarar que la Alfabetización audiovisual significa que con intención reflexiva, interpretativa y propositiva (más allá de las competencias las apetencias), es necesario adentrarse a explorar los textos audiovisuales con las herramientas básicas de un análisis textual. 1. Identificar los elementos morfológicos de un audiovisual. 2. Interpretar sus significados, descubrir figuras retóricas y analogías. 3. Ser receptor@s activ@s de los mensajes audiovisuales, los impactos emotivos producidos por las imágenes. 4. Pensarse la “indefensión" del humano ante el "gran poder de seducción" de los audiovisuales. 5. Prepararse y preparar para sobrevivir en un mundo donde las relaciones simbólicas de los audiovisuales son las que configuran las "realidades".

Estas actitudes deben estar guiadas por unas actividades específicas que significan hacer un zoom a detalles que se pierden en el gran plano general. La modalidad de los talleres específicos, que deben ser diseñados por la docente según las características del grupo, funcionan en la medida que asumen el lenguaje audiovisual como un todo constituido de partes donde cada parte es un todo a la vez y precisa de una lectura detenida. Y permiten a cada participante reconocer conceptos fundamentales y realizar su aplicación creativa, de manera que para realizar tal o cual actividad, debe dialogar desde su individualidad con el otro colectivo.

La labor como docente que guía un seminario taller en esta disciplina, debe concentrarse en preparar talleres específicos que didacticen las teorías y permitan que la comunidad 
estudiantil aplique, experimente, sus posibilidades creativas. Las ganancias de este proceso están aseguradas pues se parte de la creación literaria, que va desde la planeación del proyecto, pasando por la construcción de textos narrativos de diversa índole (Biografías de personajes, sinopsis, story line, argumento, descripción de ambientes), hasta llegar a la grabación de ejercicios audiovisuales (de corta duración) que condensan este proceso. Mi propuesta es la siguiente para un curso de Fundamentación sobre lenguaje audiovisual, o su sinónimo Alfabetización audiovisual. Ocho talleres diseñados e implementados a razón de uno por sesión, en los que se evidencie un proceso de aprendizaje anclado a la escritura, a la transdisciplinariedad, a la experimentación con las nuevas tecnologías, considerando el indispensable manejo de estos lenguajes que debe tener una persona que se prepare en la universidad para ser docente escolar y avanzar en sus estudios académicos.

A continuación presento brevemente y de manera general cada uno de los talleres que he implementado en mis cursos impartidos como parte del plan de estudios de Licenciatura en Literatura de la Escuela de Estudios Literarios de la Universidad del Valle. El primer taller de estas secuencias dinamizadoras se titula Morfología audiovisual, tiene como objetivo identificar los elementos morfológicos del lenguaje audiovisual. La descripción conceptual alude a que así como el lenguaje verbal tiene unas directrices de constitución, el lenguaje audiovisual se configura según una gramática, una sintaxis y una semántica que permiten estructurar mensajes, narrar, dar significado y sentido a determinados contenidos de imagen y sonido. Las actividades a realizar parten de la actividad fundamental, concentrada en identificar en una imagen fija: fotografía de diversos motivos: Situaciones animales, humanas, objetuales, de obras de arte; los siguientes elementos: punto, línea, forma, encuadre, luz, color. Previamente 1@s estudiantes han recibido información sobre estos conceptos heredados de la teoría del dibujo. Aquí las enseñanzas básicas de Paul Klee son precisas.

El segundo taller se titula Comunicación visual, comunicación gestual, comunicación icónica. Se propone identificar las características de cada tipo de comunicación; reconocer las diversas interacciones entre imágenes y sujetos; incentivar en cada estudiante la estructuración dinámica de enunciados espontáneos. La intención parte de relacionar individuo -espacio -productos audiovisuales - expresión oral y escrita, de allí que su descripción conceptual parta de reflexionar sobre la inmersión del mundo contemporáneo 
en ciudades donde el mercado y su publicidad invaden el espacio audiovisual es necesario sensibilizar e instruir a la comunidad estudiantil sobre estos espacios, reflexionar sobre lo que transmiten y permitirles hacer la metacognición de sus opiniones ancladas a su vida cotidiana, a su lectura de ciudad, a su vida académica y a su vida artística.

La tercera propuesta se titula Interpretar significados de representaciones icónicas y su objetivo es precisar la definición de este concepto que da Román Gubern en la relación que hay entre el producto audiovisual, quien especta y su mundo sociocultural. Es indispensable que cada estudiante sepa reconocer el marco de "convenciones culturales representativas de cada época, lugar, situación comunicacional, medio, género y estilo icónico” en el que se inscriben las formas simbólicas contenidas cada obra audiovisual. (La mirada opulenta. 1992). Las actividades relacionadas consistirán en la expectación de dos cortometrajes y la reflexión sobre los conceptos representaciones hiperformalizadas, representaciones formalizadas y representación icónica, a partir de lo propuesto por cada audiovisual leído. El cuarto taller lleva por título Búsquedas audiovisuales y pretende que cada estudiante realice un rastreo por las bases de datos, las video tiendas, las películas on-line, las videotecas, en busca de filmes que satisfagan sus curiosidades artísticas y despierten su interés investigativo, de manera que debe presentar ante el colectivo del curso el resultado de su pesquisa a la manera de una reseña escrita y una selección de imágenes extraídas de las películas seleccionadas.

El taller número 5 titulado Sintaxis audiovisual: creación de mapas de imágenes y sonidos tiene por objetivo afianzar los preceptos teóricos de la sintaxis audiovisual, a través de la creación de un producto audiovisual en el que cada estudiante deberá realizar un video corto (máximo 5 minutos) en el que arme un grupo de imágenes y sonidos que le permita armar un mapa en el que transiten sus reflexiones sobre la creación audiovisual y el mundo contemporáneo.

El sexto taller estará dedicado a la Semántica audiovisual: Descubrir figuras retóricas haciéndolas audiovisuales pretende que cada estudiante partiendo de la teoría de las figuras retóricas, cree un texto audiovisual en el que ejemplifique una de ellas. La duración será de un minuto máximo.

El taller número 7 se titula Anuncios publicitarios: analogías. Dada la inmersión de la publicidad y en general de todos los medios masivos en la vida cotidiana y cultural, 
considerando la intimación del ser humano con las Tics, es indispensable asumir esta "migración cultural" (Monsivais:) desde la metacognición y el desglosamiento de sus discursos. Cada estudiante encontrará herramientas de análisis para ingresar a los anuncios publicitarios que más le impacten. De la mano con la estructura de Gubern (1992) se identificarán en el texto publicitario: Tipo de anuncio, recursos que utiliza, valores que transmite, mensajes advertidos y mensajes inadvertidos. Cada estudiante presentará esto ante el colectivo del curos con una videograbación del comercial seleccionado.

Las actividades preparadas para la realización del taller número 8 están encaminadas a que cada estudiante encuentre en La narración icónica con imágenes fijas una herramienta expresiva y una posibilidad de adentrarse a conocer relatos impensados, en un formato que para el arte significa la confluencia de la literatura, la historia y el dibujo de manera idónea, pues son digeribles hasta para los lectores más anoréxicos. Así que cada estudiante deberá escoger un cómic, historieta o tebeo de su máximo gusto para identificar siguiente: La secuencia de las viñetas. La permanencia de un personaje a lo largo de la serie. En los globos o bocadillos ¿Cómo se expresan los personajes? ¿Cuáles interjecciones usa? ¿Cuáles palabras prefiera cada personaje? ¿Cuánto tiempo dura cada historieta? ¿Cuánto duran las elipsis? Por ejemplo, ¿cuáles acontecimientos se omiten? Teniendo en cuenta que la eficacia del cómic en el manejo de la economía del lenguaje y del intervalo entre el tiempo y la narración, este taller titulado Mi historieta favorita: La narración icónica con imágenes fijas. Dejará a cada estudiante en un nivel que le permite proponer, ser creativo y crítico en sus actividades cotidianas, de manera que decante alguna porción de la inmensidad informativa recibida por segundo.

Así llega la propuesta a su taller final, titulado Realizo un video con lo aprendido durante los ocho talleres anteriores, donde se pretende que cada estudiante cree un video corto, de tema libre, utilizando los conocimientos adquiridos con antelación. Las herramientas de planeación serán las básicas de escaletear el relato, clarificar su conflicto, su estructura dramática y a grabar...

La implementación de esta propuesta me ha demostrado que conocer de manera estructural y simbólica el lenguaje audiovisual, utilizando las herramientas que proporcionan artes como la literatura, el dibujo, el cine o diversas teorías de la comunicación, cinematográficas, guionísticas, de diseño, antropológicas potencia las actividades de 
escritura, la lectura crítica y el sentido histórico de cada estudiante, enfrentado a la cantidad ingente de imágenes y sonidos ávidas de captar toda su atención.

Así como el lenguaje verbal tiene unas directrices de constitución, el lenguaje audiovisual se configura según una gramática, una sintaxis y una semántica que permiten estructurar mensajes, narrar, dar significado y sentido a determinados contenidos. Solamente adentrándonos en sus filigranas podremos resignificar las maneras expresivas del arte, de la industria, del comercio, de la tecnología y de la educación. Matar la metáfora para engendrar una metonimia, armar el decollage que significa rasgar nuestros saberes insertados en microchip genético del código binario y dar paso al florecimiento de la multiplicidad creativa.

\section{Bibliografía}

Balle, Francis y Gérard Eymery, Los nuevos medios de comunicación masiva, México: Fondo de cultura económica, 1989.

Barbero, Jesús Martín y Sonia Muñoz, Televisión y melodrama, Colombia: 1990?

Barthes, Roland, La cámara lúcida. Barcelona: Paidós. 1997.

Baudrillard, Jean. Pantalla total. Barcelona: Anagrama, 2000.

Bernal, Germán, González, Julián, Gómez, Rocío del Socorro, Nuestra casa, nuestras pantallas: manual de convivencia con las pantallas audiovisuales Colombia: Comisión Nacional de Televisión, 2004.

Casseti, Francesco y Federico di Chio. Cómo analizar un film, Barcelona: Paidós, 1990.

Eco, Umberto. Apocalípticos e integrados ante la cultura de masas. Barcelona: Lumen. 1977.

Eisenstein, Sergei Mickhailovich, La forma del cine, México: Siglo Veintiuno Editores, 1986.

-, El sentido del cine, Argentina: Argentina Editores, S.A, 1974.

Ferrés, Joan. Televisión y educación. Barcelona: Paidós, 1994.

Esnaola, Graciela Alicia. Claves culturales en la construcción de conocimiento: ¿qué enseñan los videojuegos? Buenos Aires: Alfagrama ediciones. 2006.

Gubern, Roman, La mirada opulenta. Una exploración a la iconosfera contemporánea. México: Editorial Gustavo Gili, 1992. 
---------------, El eros electrónico, España: Santillana, 2000.

Klee, Paul. Bases para la estructuración del arte. Traducción y prólogo Iván Balberg.

Buenos Aires: Editorial Andrómeda, 2003.

La Feria, Jorge (Compilador). Cine, video y multimedia: la ruptura de lo audiovisual.

Turkle, Sherry, La vida en la pantalla. La construcción de la identidad en la era del

Internet, España: Paidós, 1997. 